\title{
Salivary histatin 3 inhibits heat shock cognate protein 70-mediated inflammatory cytokine production through toll-like receptors in human gingival fibroblasts
}

Yasuhiro Imamura ${ }^{1 *}$ and Pao-Li Wang ${ }^{2}$

\begin{abstract}
Background: Salivary histatins are bioactive peptides related to the innate immune system associated with antimicrobial activities. However, very little is known about the physiological and biological functions of histatins against host cells or their role in oral cell inflammation. Histatin 3 binds to heat shock cognate protein 70 (HSC70, a constitutively expressed heat shock protein (HSP)). It is unclear whether HSC70 is involved in the inflammatory response in oral cells. Injured oral cells release some intracellular proteins including HSC70. It is possible that released HSC70 induces toll-like receptor (TLR) activation, just as extracellular HSP70 (a stress inducible HSP) does, and that histatin 3 affects this process. Therefore, we tested the hypothesis that HSC70 activates TLR signaling and histatin 3 inhibits this activation and inflammatory cytokine production.
\end{abstract}

Methods: A nuclear factor (NF)-KB-dependent luciferase reporter plasmid was transfected into HEK293 cells stably expressing TLR2 with coreceptor CD14 (293-TLR2/CD14 cells) or stably expressing TLR4 with CD14 and the accessory molecule MD2 (293-TLR4/MD2-CD14 cells). The cells were stimulated with HSC70 in the presence or absence of histatin 3, and examined using luciferase assays. We also stimulated human gingival fibroblasts (HGFs) with HSC70 with or without histatin 3. Then, we analyzed the levels of inflammatory cytokines (interleukin (IL)-6 and IL-8) in the culture media. Cell proteins were analyzed using enzyme-linked immunosorbent assay and Western blotting with antibodies of mitogen-activated protein kinases and NF-KB inhibitor IKB-a, respectively. Histatin 3-bound form of HSC70 was analyzed using limited V8 protease proteolysis.

Results: HSC70 induced NF-KB activation in a dose-dependent manner in 293-TLR2/CD14 and 293-TLR4/MD2-CD14 cells, and histatin 3 inhibited this process and when histatin 3 binding to HSC70 was precluded by 15-deoxyspergualin, which augmented NF-KB-triggered activation. In HGFs, histatin 3 also inhibited HSC70-induced inflammatory cytokine production, extracellular signal-regulated protein kinase phosphorylation, and degradation of IKB-a. Moreover, HSC70 in the presence of histatin 3 was relatively resistant to digestion by V8 protease compared with HSC70 in the presence of control peptide.

Conclusions: Histatin 3 may be an inhibitor of HSC70-triggered activation of TLR signaling and inflammatory cytokine production and may be involved in inflammation processes noted in oral cells.

Keywords: Histatin, Inflammatory cytokine, Toll-like receptor, HSC70

\footnotetext{
* Correspondence: yimamura@po.mdu.ac.jp

'Department of Pharmacology, Matsumoto Dental University, Shiojiri,

Nagano, Japan

Full list of author information is available at the end of the article
}

\section{Biomed Central}

(c) 2014 Imamura and Wang; licensee BioMed Central Ltd. This is an open access article distributed under the terms of the Creative Commons Attribution License (http://creativecommons.org/licenses/by/2.0), which permits unrestricted use, distribution, and reproduction in any medium, provided the original work is properly cited. 


\section{Background}

Histatins constitutively secreted by the salivary glands are associated with innate immunity processes in the oral cavity. These peptides have antimicrobial properties and protect oral tissues from pathogens [1]. The histatin family comprises 12 histidine-rich cationic peptides found in healthy adults at concentrations of $50-425 \mu \mathrm{g} / \mathrm{ml}$, corresponding to approximately $10 \%$ of total protein in saliva [2-4]. Histatins 1 and 3 are full-length peptides of 38 and 32 amino acid residues, respectively; other characterized members of the histatin family are proteolytic products formed during secretion [2,5]. Histatins 3 and 5 are the heat shock protein (HSP)-binding proteins that are most abundant in saliva and are active against Candida albicans and Porphyromonas gingivalis (the pathogen of periodontitis) [6-10]. In addition, histatins 3 and 5 are also involved in proliferation of human gingival fibroblasts (HGFs) and rabbit costal chondrocytes, respectively $[7,11]$.

HSPs are induced by a wide variety of stresses in prokaryotic and eukaryotic cells, including environmental, pathological, and physiological stimuli [12]. HSPs function as ATPase activity-dependent molecular chaperones that assist in the correct folding of proteins, the assembly of various protein complexes, transport of proteins across membranes into organelles, and the degradation of proteins by the lysosome [13-15]. Heat shock cognate protein 70 (HSC70), an HSP family member, is a cytosolic protein that is abundantly, constitutively, and ubiquitously expressed in most cells [16]. HSC70 consists of an ATPase domain (amino acid residues 1-384), a substrate (peptides, including histatin 3)-binding domain (amino acid residues 385-543), and a lid domain (amino acid residues 544-646) [7,17]. Three-dimensional structure of the ATPase domain has been determined by $\mathrm{X}$-ray crystallography; the structure of this domain is similar to that of hexokinase and actin $[18,19]$.

Toll-like receptors (TLRs) have been identified as human homologs of Drosophila Toll receptors, which are involved in innate immunity [20,21]. TLRs recognize their respective pathogen-associated molecular patterns (PAMPs) and damage-associated molecular patterns (DAMPs, such as intracellular proteins released from damaged and necrotic cells) [22]. TLR2, a TLR family member, recognizes peptidoglycan (PGN, a major cell-wall component of gram-positive bacteria), lipopolysaccharide (LPS) from P. gingivalis, and HSP70 (a stress-induced HSP) [23-25]. TLR4 is another TLR family member, which recognizes LPS from the outer membranes of gramnegative bacteria and HSPs such as HSP70, HSP60, and Gp96 [25-28]. TLR2 and TLR4 require their interacting proteins for the recognition of some PAMPs and DAMPs. TLR2 can induce nuclear factor (NF)- $\mathrm{B}$ activation in response to HSP70 stimulation, but only in the presence of CD14, a glycosylphosphatidylinositol-anchored protein
[25]. In order for TLR4 to function satisfactorily as a receptor for LPS, both MD2 and CD14 must be coexpressed [29,30]. Once TLR2 and TLR4 recognize their respective ligands, the specific response initiated by these TLRs depends on the recruitment of adaptor proteins (e.g., myeloid differentiation primary response protein 88 or Tollinterleukin (IL)-1 receptor domain-containing adaptor protein). These adaptor proteins transmit signals that result in the activation of mitogen-activated protein kinases (MAPKs) and NF-kB and the induction of inflammatory cytokines [31].

It is not known whether HSC70 is involved in the inflammatory responses in oral cells, such as the production of inflammatory cytokines. It has been proposed that oral diseases accompanying damage or oral injuries cause the release of some intracellular proteins, including HSC70. If HSC70, like HSP70, functions as DAMPs, HSC70 could be a putative inducible factor in the inflammatory response in oral cells through TLRs. HGFs, which constitute the major cellular population of gingival tissue, express TLR2, TLR4, MD2, and CD14 [32-34]. In addition, histatin 3 in saliva may associate with the released HSC70. Therefore, we can infer that histatin 3 inhibits TLR-mediated HSC70 function, reducing the production of inflammatory cytokine in oral cells.

In this study, we identified HSC70 as a putative ligand of TLR2 and TLR4. We observed the inhibitory effect of histatin 3 on inflammatory cytokine production in HGFs and on NF- $\mathrm{KB}$ activation in HEK293 cells expressing TLR2 or TLR4 as a result of HSC70 stimulation. These findings represent our current knowledge of physiological functions of salivary proteins in oral cavity.

\section{Methods}

\section{Cell cultures}

The stable cell lines, 293-TLR4/MD2-CD14 (InvivoGen) and 293-TLR2/CD14 (InvivoGen) and HGFs were cultured in Dulbecco's modified Eagle medium (DMEM; SigmaAldrich) with $10 \%$ fetal bovine serum (FBS), 100 units $/ \mathrm{ml}$ of penicillin $\mathrm{G}$, and $100 \mu \mathrm{g} / \mathrm{ml}$ of streptomycin at $37^{\circ} \mathrm{C}$ in $5 \% \mathrm{CO}_{2}$ and $95 \%$ air in a humidified incubator. HGFs were collected from volunteers after obtaining appropriate informed consent. The Ethics Committee of Matsumoto Dental University approved the study protocol.

\section{Reagents}

The following materials and antibodies were purchased: LPS from Escherichia coli 0128:B12 (Sigma-Aldrich); LPS from $P$. gingivalis (InvivoGen); recombinant human HSP70 (Stressgen; endotoxin activity, $<0.05$ endotoxin units $(\mathrm{EU}) / \mu \mathrm{g})$; recombinant bovine HSC70 (Stressgen; $<0.05 \mathrm{EU} / \mu \mathrm{g})$; recombinant bovine HSC70 ATPase fragment (Enzo Life Sciences; $0.1 \mathrm{EU} / \mu \mathrm{g}$ ); V8 protease (Roche); 15-deoxyspergualin (DSG) (Spanidin ${ }^{\bullet}$ Inj.; Nippon 
Kayaku); mouse monoclonal anti-TLR4 (HTA125) and antiTLR2 (TL2.1) antibodies (Hycult Biotechnology); mouse monoclonal anti-CD14 (MY4) antibody (Beckman Coulter); rabbit polyclonal anti-p44/42, anti-p38, anti-phosphorylated p38, anti-phosphorylated IкB- $\alpha$, mouse monoclonal antiphosphorylated p44/42 antibodies (Cell Signaling); mouse monoclonal anti-JUN-N-terminal protein kinase (JNK) (D-2), anti-phosphorylated JNK (G-7), anti-IKB- $\alpha$ (H-4) antibodies (Santa Cruz Biotechnology); and mouse monoclonal anti- $\beta$-actin antibody (Abcam). Endotoxin levels of all materials used were determined using a ToxinSensor chromogenic LAL endotoxin assay kit (GenScript), and the resultant level was low $(\sim 0.1 \mathrm{EU} / \mu \mathrm{g})$. The LPS, bovine serum albumin (BSA), HSP70, HSC70, and the HSC70 ATPase fragment were heated at $95^{\circ} \mathrm{C}$ for $20 \mathrm{~min}$.

\section{Peptides}

Human histatins 3, 4, and 5 and P3a peptide (Biosynthesis Inc.) were chemically synthesized [7]. The control peptide, (Pro-Pro-Gly) $10 \cdot 9 \mathrm{H}_{2} \mathrm{O}$, was purchased from Peptide Institute Inc.

\section{Transfection and luciferase assays}

pIgkB-Luc $(1 \mu \mathrm{g})$ and pRSV- $\beta$-gal $(0.1 \mu \mathrm{g})$, as the standard plasmid, were mixed with TransIT-LT1 transfection reagents (Mirus) [35]. The mixtures were transfected into $3 \times 10^{5}$ cells. One day after transfection, the cells were stimulated using LPSs from E. coli $(20 \mathrm{ng} / \mathrm{ml})$ or $P$. gingivalis $(100 \mathrm{ng} / \mathrm{ml})$. For 293-TLR4/MD2-CD14 cells, the incubation mixtures also contained 1.4 or $14 \mathrm{nM}$ BSA, HSP70, or HSC70 or $14 \mathrm{nM}$ heated HSP70, heated HSC70, or the HSC70 ATPase fragment (heated or unheated). For 293-TLR2/CD14 cells, the incubation mixtures contained 2.8 or 28 nM BSA, HSP70, or HSC70 or $28 \mathrm{nM}$ heated HSP70, heated HSC70, or the HSC70 ATPase fragment (heated or unheated). Cells were harvested and lysed $6 \mathrm{~h}$ after stimulation. Luciferase and $\beta$-galactosidase activities in the lysates were measured as
A

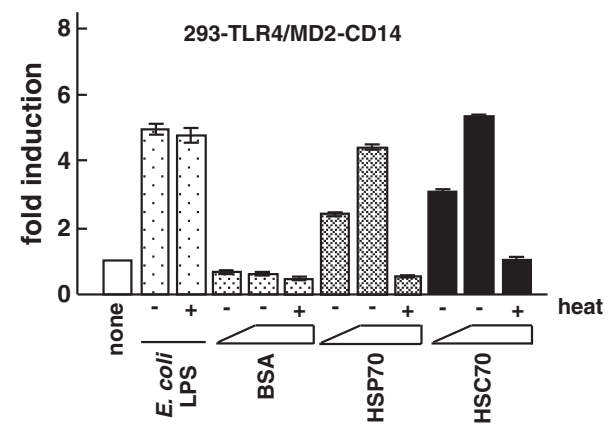

C

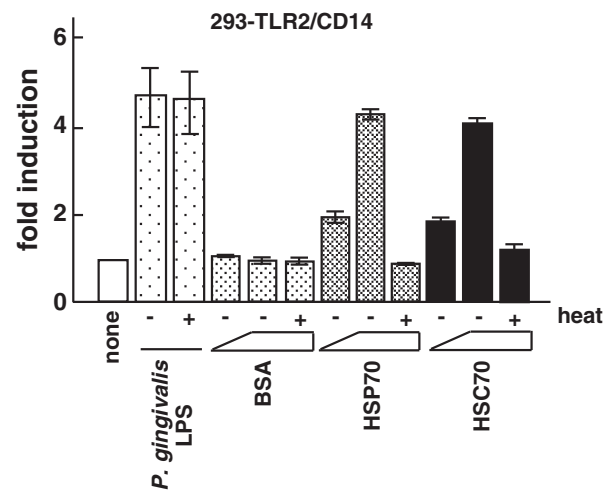

B

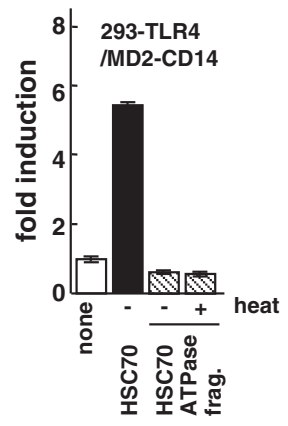

D

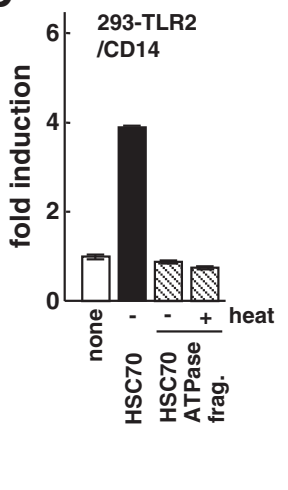

Figure 1 The effect of HSC70 on NF-KB-dependent activation through TLR2 and TLR4. (A) Luciferase assays for NF-kB-dependent activation by HSC70 through TLR4. 293-TLR4/MD2-CD14 cells were transfected with an NF-KB-dependent luciferase reporter plasmid (plgkB-Luc). One day after transfection, cells were stimulated with heated and unheated E. coli LPS, BSA, HSP70, or HSC70 for 6 h. Cell lysates prepared from the stimulated cells were analyzed by luciferase assays. The values are shown as fold induction of the standardized luciferase activity over the unstimulated control (none). (B) Luciferase assays for NF-KB-dependent activation by the ATPase fragment of HSC70 in 293-TLR4/MD2-CD14 cells. The procedures were as in (A), except that the cells were stimulated with the heated or unheated HSC70 ATPase fragment. (C) Luciferase assays for NF-kB-dependent activation by HSC70 through TLR2. The procedures were as in (A), except that 293-TLR2/CD14 cells and P. gingivalis LPS were used. (D) Luciferase assays for NF-KB-dependent activation by the HSC70 ATPase fragment in 293-TLR2/CD14 cells. The procedures were as in (A and B). Bars represent the means and range of duplicate samples. 
described previously [35]. The luciferase activities were compared after normalization against the standard ( $\beta$-galactosidase activity). For the peptide experiments, the stimulant $(20 \mathrm{ng} / \mathrm{ml}, E$. coli LPS or $14 \mathrm{nM}$, HSP70 or HSC70 for 293-TLR4/MD2-CD14 cells; $100 \mathrm{ng} / \mathrm{ml}$, P. gingivalis LPS or $28 \mathrm{nM}$, HSP70 or HSC70 for 293-TLR2/ CD14 cells) and respective peptides ( 3 or $30 \mu \mathrm{M}$; stimulation with peptide alone, $30 \mu \mathrm{M})$ were mixed. For the DSG experiments, HSC70 (14 nM for 293-TLR4/MD2-CD14 cells and $28 \mathrm{nM}$ for 293-TLR2/CD14 cells) and the peptides $(30 \mu \mathrm{M})$ were mixed with DSG $(10 \mu \mathrm{g} / \mathrm{ml})$. All the above mixtures were placed on ice for $30 \mathrm{~min}$ before being added to transfected cells. The cells were then cultured for $6 \mathrm{~h}$. Figures show representative examples of 3 identical experiments with essentially identical results.

\section{Western blotting}

HGFs $\left(1.2 \times 10^{5}\right)$ were cultured in DMEM containing $0.1 \%$ $0.5 \%$ FBS for $24 \mathrm{~h}$. Cells were stimulated using $10 \mathrm{ng} / \mathrm{ml}$ LPS or $0.5 \mu \mathrm{g} / \mathrm{ml} \mathrm{HSC70} \mathrm{for} \mathrm{the} \mathrm{indicated} \mathrm{time} \mathrm{periods.} \mathrm{For}$ peptide experiments, $1.5 \mu \mathrm{g} / \mathrm{ml} \mathrm{HSC70}$ and 0.05 or $0.5 \mu \mathrm{M}$ peptides (stimulation of peptide alone, $0.5 \mu \mathrm{M}$ ) were mixed and placed on ice for $15 \mathrm{~min}$. The mixtures were added to low serum-cultured HGFs. After $30 \mathrm{~min}$, the cells were lysed with radioimmunoprecipitation assay (RIPA) buffer (50 mM, Tris- $\mathrm{HCl}$ (pH 7.5); $5 \mathrm{mM}$, EDTA; $150 \mathrm{mM}$, $\mathrm{NaCl} ; 1 \% \mathrm{NP}-40 ; 0.1 \%$ sodium dodecyl sulfate (SDS); $0.5 \%$ sodium deoxycholate; $1 \mathrm{mM}$, phenylmethylsulfonyl fluoride; $10 \mu \mathrm{g} / \mathrm{ml}$, leupeptin; $10 \mu \mathrm{g} / \mathrm{ml}$, aprotinin; $5 \mathrm{mM}, \mathrm{Na}_{3} \mathrm{VO}_{4}$; $10 \mathrm{mM}, \mathrm{NaF})$. Western blotting analyses were performed as previously described [35,36]. Figures of Western blotting are representative of 3 independent experiments with similar results. Relative band intensity was measured using the ImageJ software (http://imagej.nih.gov/ij/).

\section{Enzyme-linked immunosorbent assays (ELISAs)}

HGFs $\left(1 \times 10^{4}\right)$ were cultured with HSC70 $(7$ or $70 \mathrm{nM})$, heated HSC70 $(70 \mathrm{nM})$, or the unheated or heated
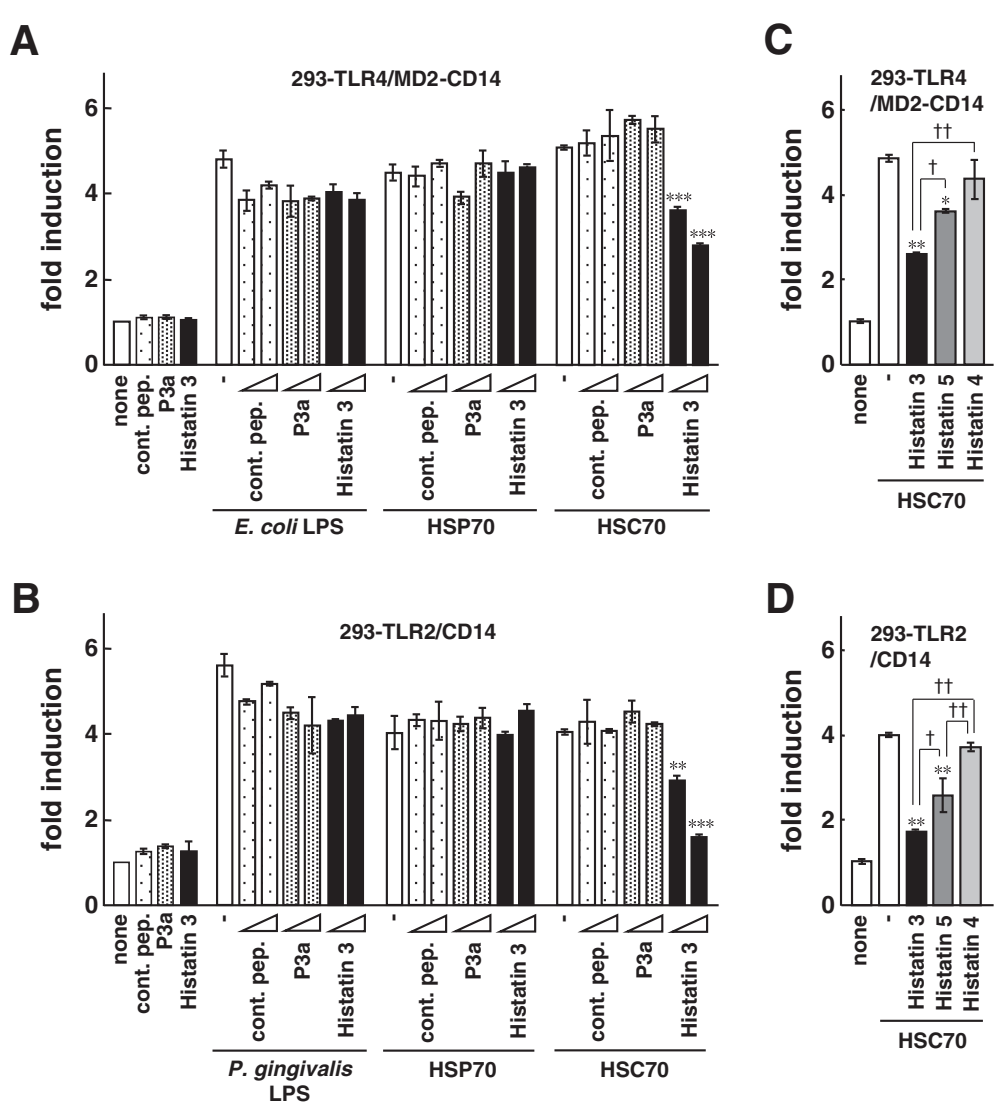

Figure 2 The effect of histatin 3 on NF-KB-dependent activation by HSC70 through TLR2 and TLR4. (A, B) Luciferase assays for NF-KBdependent activation by HSC70 through TLR2 and TLR4 in the presence of histatin 3. 293-TLR4/MD2-CD14 (A) and 293-TLR2/CD14 (B) cells were transfected with plgkB-Luc, and were stimulated with mixtures of the indicated peptides and LPS, HSP70, or HSC70 for 6 h. Cell lysates prepared from the stimulated cells were analyzed by luciferase assays. The values are shown as fold induction of the standardized luciferase activity over the unstimulated control (none). ${ }^{* *}, \mathrm{P}<0.01$; ${ }^{* *}, \mathrm{P}<0.001$ versus stimulation with HSC70 alone. cont. pep., control peptide. (C, D) Luciferase assays for NF-KB-dependent activation by HSC70 through TLR2 and TLR4 in the presence of histatin family members. The procedures were same as in (A and B), except that stimulations were with mixtures of HSC70 and histatins 3, 4, or 5. Bars represent the means and range of duplicate samples. ${ }^{*}, \mathrm{P}<0.05 ;{ }^{* *}, \mathrm{P}<0.01$ versus stimulation with $\mathrm{HSC70}$ alone.,$+ \mathrm{P}<0.05 ;+\dagger, \mathrm{P}<0.01$. 
HSC70 ATPase fragment (70 nM) for $24 \mathrm{~h}$. For antibody experiments, HGFs were cultured with $10 \mu \mathrm{g} / \mathrm{ml}$ antiTLR4, anti-TLR2, or anti-CD14 antibodies for $1 \mathrm{~h}$. LPSs (from $E$. coli, $10 \mathrm{ng} / \mathrm{ml}$; from $P$. gingivalis, $5 \mathrm{ng} / \mathrm{ml}$ ) and HSC70 (70 nM) were then added to the cells, and the cells were cultured for $24 \mathrm{~h}$. For peptide experiments, HSC70 $(70 \mathrm{nM})$ and peptides $(0.15 \mu \mathrm{M}$ and $1.5 \mu \mathrm{M})$ were mixed and placed on ice for $15 \mathrm{~min}$. The mixtures were added to the cells and cultured for $24 \mathrm{~h}$. The culture media from all the above experiments were collected, and levels of IL-6 and IL-8 were measured using CytoSet kits (Biosource). Figures show representative examples of three identical experiments with essentially identical results.

\section{Limited proteolysis with V8 protease}

HSC70 $(2.1 \mu \mathrm{M})$ and peptides $(10.5 \mu \mathrm{M})$ in a buffer (50 mM, Tris- $\mathrm{HCl}$ (pH 8.0); $0.5 \mathrm{mM}$, DTT; $150 \mathrm{mM}$, $\mathrm{NaCl}$ ) were placed on ice for $10 \mathrm{~min}$. After the addition of V8 protease (75 or $750 \mathrm{ng}$ ), the mixtures were incubated at $30^{\circ} \mathrm{C}$ for $1.5 \mathrm{~h}$. The reactions were terminated by the addition of 0.5 volume of $2 \times$ SDS sample buffer (140 mM, Tris-HCl (pH 7.0); 6\% SDS; 10\% mercaptoethanol; $22.4 \%$ glycerol; $0.02 \%$ bromphenol blue; and $2 \mathrm{mM}$, phenylmethylsulfonyl fluoride). The samples were heated at $100^{\circ} \mathrm{C}$ for $5 \mathrm{~min}$, and the proteolytic fragments were resolved using 12\% SDS-polyacrylamide gel electrophoresis (PAGE) gels, followed by staining with Coomassie Brilliant Blue. Figure is representative of 3 independent experiments with similar results.

\section{Statistical analysis}

All quantitative data were statistically analyzed using either one-way analysis of variance (ANOVA) or two-way ANOVA using the StatMate software (ATMS). Differences were considered statistically significant at $\mathrm{P}<0.05$.

\section{Results}

NF-KB activation by stimulation with exogenous HSC70 through TLR2 and TLR4

HSP70 stimulates inflammatory cytokine production (e.g., IL-6 and tumor necrosis factor- $\alpha$ ) in monocytes and dendritic cells through TLR2 and TLR4 [25,37]. However, the activation of inflammatory cytokine production by HSC70, even though it belongs to the same HSP family as HSP70, is poorly understood. Therefore, we investigated whether cytokine production by HSC70 is mediated by TLRs and their interacting proteins such as HGFs, particularly in oral cells. Because HGFs express TLR2 and TLR4, it is necessary to perform systematic experiments investigating the dependence of HSC70 stimulation on TLR2 or TLR4. It has been reported that HSP70 stimulation induces NF- $\mathrm{KB}$ activation in 293T cells transiently expressing TLR4 and MD2, but not in the cells expressing TLR4 alone [38]. In contrast, till now there has been no evidence that HSC70 activates NF-kB in HEK293 cells expressing TLRs. Therefore, we examined NF- $\mathrm{kB}$ activation in the stable cell line 293TLR4 (HEK293 cells constitutively expressing TLR4) transiently transfected with an MD2 expression vector and an NF-kB-dependent luciferase reporter plasmid.

\section{A}

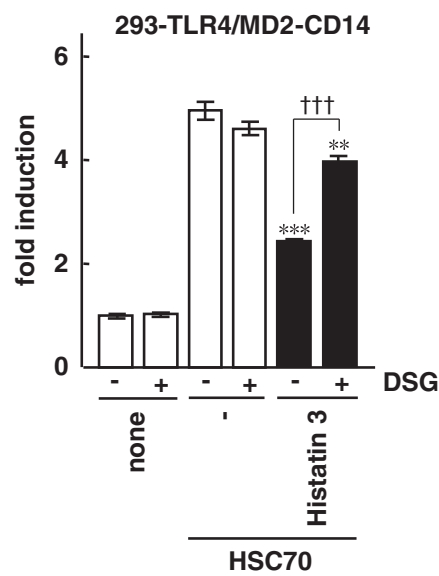

B

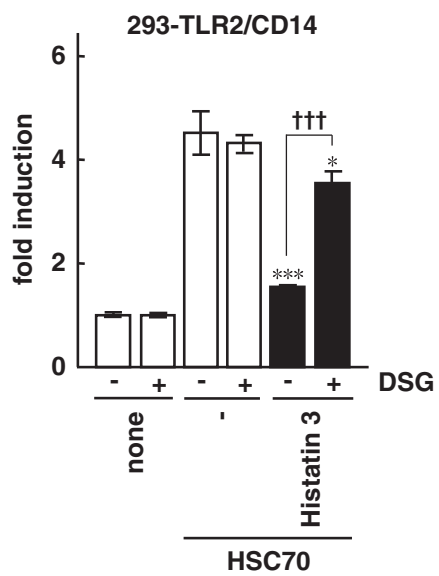

Figure 3 The effect of DSG on NF-KB-dependent activation by HSC70 through TLR2 and TLR4 in the presence of histatin 3 . One day after transfection with plgkB-Luc in 293-TLR4/MD2-CD14 (A) and 293-TLR2/CD14 (B) cells, the cells were stimulated with HSC70 with or without histatin 3 in the presence or absence of DSG for $6 \mathrm{~h}$. Cell lysates prepared from the stimulated cells were analyzed by luciferase assays. The values are shown as fold induction of the standardized luciferase activity over the unstimulated control (none, DSG (-)). Bars represent the means and range of duplicate samples. ${ }^{*}, \mathrm{P}<0.05{ }^{* *}, \mathrm{P}<0.01{ }^{* * *}, \mathrm{P}<0.001$ versus stimulation with HSC70 alone. †十†, $\mathrm{P}<0.001$. 
The results indicated that HSC70 stimulated NF-kBdependent promoter activity through TLR4/MD2 signaling pathway. Moreover, when CD14 and MD2 were both expressed in 293-TLR4 cells, the promoter activation by HSC70 was more effective than that in 293-TLR4 cells transiently expressing MD2 alone (data not shown). We then examined whether this activation was dosedependent. The stable cell line 293-TLR4/MD2-CD14 (HEK293 cells constitutively expressing TLR4, MD2, and CD14) transfected with the NF-kB-dependent reporter plasmid (293-TLR4/MD2-CD14/NF-kB) was stimulated with $\mathrm{HSC70}$, and luciferase assays were performed. As shown in Figure 1A, both HSC70 and HSP70 (control) induced promoter activation in a dose-dependent manner, whereas BSA did not. Promoter activity levels with heated HSC70 and HSP70 were similar to those in unstimulated cells. When 293-TLR4/MD2-CD14/NF-kB cells were stimulated with the heated or unheated HSC70 ATPase fragments (HSC70 with deletions of the substrate-binding and lid domains), the promoter activation was at a lower level (Figure 1B). These results suggest that HSC70 as well as E. coli LPS induces NF- $\mathrm{kB}$ activation through TLR4/MD2/CD14 system.

HSP70 also induces NF-kB activation in stable HEK293TLR2 cells transiently expressing CD14, but not in HEK293-TLR2 without CD14 [25]. Therefore, we examined NF- $\mathrm{kB}$ activation by HSC70 in the stable cell line 293-TLR2/CD14 (HEK293 cells constitutively expressing TLR2 and CD14) transfected with the NF-kB-dependent reporter plasmid (293-TLR2/CD14/NF- $k B$ ). As shown in Figure 1C, HSC70 as well as HSP70 (control), but not BSA, induced the promoter activation through TLR2/ CD14 in a dose-dependent manner. Heated and unheated $P$. gingivalis LPSs induced promoter activation, whereas heated HSC70 and heated HSP70 reduced activation compared with the respective unheated HSPs. When the cells were stimulated with heated and unheated HSC70 ATPase fragments, only low levels of the promoter activation were observed (Figure 1D). These results suggest that both HSC70 and P. gingivalis LPS induce NF- $\mathrm{kB}$ activation through TLR2/CD14.

\section{Inhibitory effects of histatin 3 on HSC70-induced NF-KB activation through TLR2 and TLR4}

We have previously reported that salivary protein histatin 3 binds to HSC70, but not HSP70 [7]. Here, we examined the effects of histatin 3 on NF- $\mathrm{kB}$ activation by HSC70 through TLR2 and TLR4. 293-TLR4/MD2CD14/NF-kB and 293-TLR2/CD14/NF-kB cells were stimulated with mixtures of HSC70 and a control peptide, P3a (a peptide derived from the clathrin light chain that stimulates ATP hydrolysis through HSC70 [39]), or histatin 3, and luciferase assays were performed. The results showed that NF-kB-dependent promoter activation, stimulated by HSC70 through TLR4/MD2/CD14 or TLR2/CD14, was significantly suppressed by histatin 3 in a dose-dependent manner. Figure 2A shows results for TLR4/MD2/CD14 (histatin 3, $3 \mu \mathrm{M}(\mathrm{P}<0.001)$ and $30 \mu \mathrm{M}(\mathrm{P}<0.001))$, and Figure $2 \mathrm{~B}$ for TLR2/CD14 (histatin $3,3 \mu \mathrm{M}(\mathrm{P}<0.01)$ and $30 \mu \mathrm{M}(\mathrm{P}<0.001))$. However, histatin 3 did not affect promoter activation caused by LPS (from E. coli or P. gingivalis) or HSP70, in either cell type. Neither the control peptide nor P3a inhibited the LPS-, HSP70-, or HSC70-induced activation. We then tested whether other members of the histatin family were capable of suppressing NF-kB-dependent activation through TLR4/MD2/CD14 or TLR2/CD14. 293TLR4/MD2-CD14/NF- $\mathrm{B}$ and 293-TLR2/CD14/NF-kB cells were stimulated with mixtures of HSC70 and histatins 3 , 4, or 5, and luciferase assays were performed. As shown in Figures 2C and 2D, HSC70-induced promoter activation was significantly reduced in the presence of histatin 3 compared with that in the presence of histatin 5 ( $\mathrm{P}<0.05$ in both cell types). The suppressive effects of

A
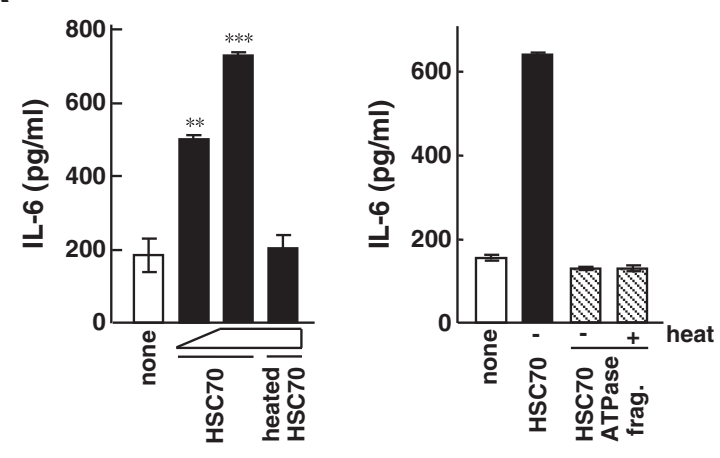

B
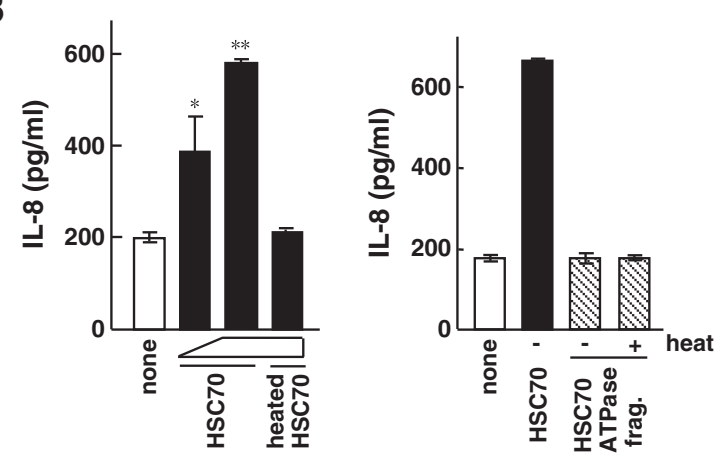

Figure 4 The effect of HSC70 on inflammatory cytokine production in HGFs. (A, B) IL-6 and IL-8 production by HSC70 stimulation in HGFs. Unheated HSC70 (7 and $70 \mathrm{nM}$ ) and heated HSC70 (70 nM) were added to HGFs (left). Unheated or heated HSC70 ATPase fragment (70 nM each) were also added to HGFs (right). The cells were cultured for $24 \mathrm{~h}$. The amounts of IL-6 (A) and IL-8 (B) in the culture media were measured by ELISAs. Bars represent the means and range of duplicate samples. ${ }^{*}, \mathrm{P}<0.05$; $*^{*}, \mathrm{P}<0.01$; $^{* *}, \mathrm{P}<0.001$ versus unstimulated (none). 
histatin 4 on the HSC70-mediated promoter activation were at low levels. These results suggest that histatin 3 bound to HSC70 inhibits HSC70-induced NF-kB activation both in TLR4/MD2/CD14 and TLR2/CD14 mode.

\section{Effect of DSG on HSC70-induced NF-KB activation through TLR2 and TLR4 in the presence of histatin 3}

We investigated whether the specific interaction of histatin 3 and $\mathrm{HSC70}$ was necessary for inhibition of HSC70-induced NF- $\mathrm{B}$ activation. The NF- $\mathrm{kB}$-driven luciferase assays were performed on 293-TLR4/MD2CD14/NF-kB and 293-TLR2/CD14/NF-kB cells treated with HSC70 along with or without histatin 3 in the presence or absence of DSG. DSG is a synthetic analog of spergualin, a natural product from Bacillus laterosporus, and has a peptidomimeric structure. It binds particularly well to HSC70 and is considered to preclude peptide binding to HSC70 $[40,41]$. The results demonstrated that in the presence of histatin 3 and DSG HSC70-stimulated NF-kB-dependent promoter activity was significantly higher than with histatin 3 alone in both 293-TLR4/ MD2-CD14 (Figure 3A, $\mathrm{P}<0.001$ ) and 293-TLR2/CD14 (Figure $3 \mathrm{~B}, \mathrm{P}<0.001$ ) cells. These results suggest that the specific binding of histatin 3 to HSC70 is important for inhibition of HSC70-mediated activation of TLR2 and TLR4 signaling activation.

\section{Production of inflammatory cytokines by $\mathrm{HSC70}$ stimulation in HGFs}

It is unknown whether HSC70 is involved in inflammatory response in HGFs, especially in the production of inflammatory cytokines. To examine this possibility,
A

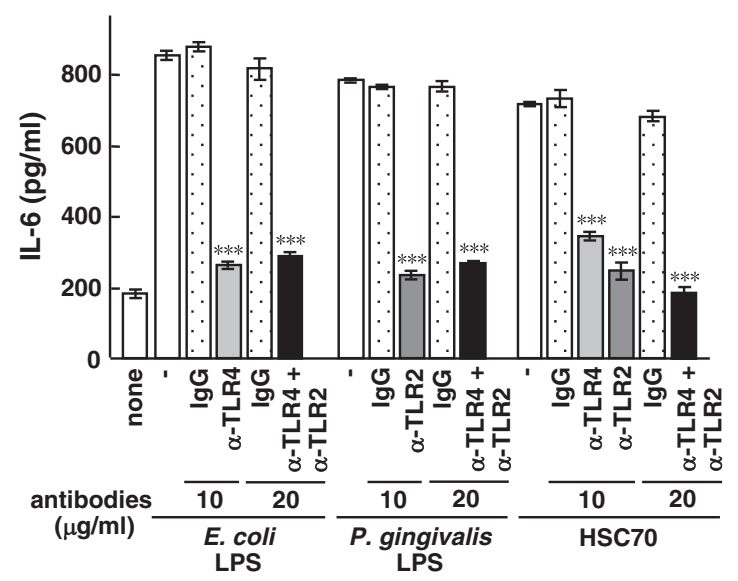

B

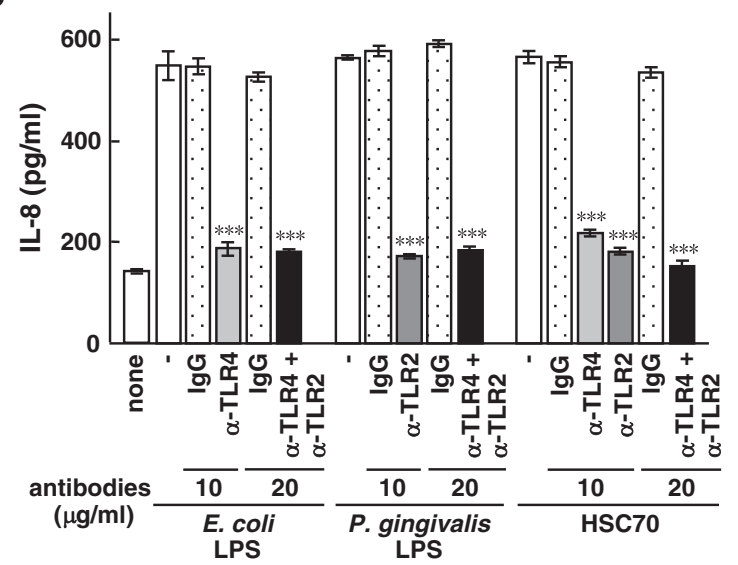

C

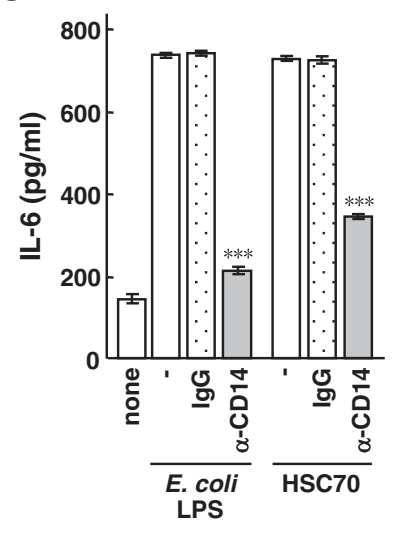

D

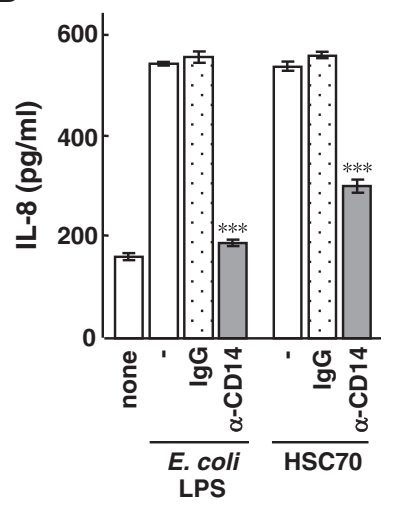

Figure 5 The effect of anti-TLR antibodies on HSC70-stimulated inflammatory cytokine production in HGFs. (A) IL-6 and (B) IL-8 production with LPS or HSC70 in the presence of anti-TLR2 and anti-TLR4 antibodies in HGFs. HGFs were cultured for $1 \mathrm{~h}$ after the addition of the antibodies and were then stimulated with LPSS or HSC70 for 24 h, and ELISAs for IL-6 and IL-8 were performed on the cultured media. (C) LPS- and HSC70-stimulated IL-6 and (D) IL-8 production in the presence of anti-CD14 antibody in HGFs. Assays were performed as described in the "Methods." IgG served as the antibody control. Bars represent the means and range of duplicate samples. ***, P $<0.001$ versus stimulation with LPS or HSC70 alone. 
HGFs were stimulated with HSC70 for $24 \mathrm{~h}$, and the amounts of IL- 6 and IL- 8 in the culture media were measured by ELISAs. As shown in Figures $4 \mathrm{~A}$ and $4 \mathrm{~B}$, unheated HSC70 significantly induced cytokine production in HGFs in a dose-dependent manner, whereas heated $\mathrm{HSC70}$ did not induce cytokine production (HSC70, $7 \mathrm{nM}(\mathrm{P}<0.01)$ and $70 \mathrm{nM}(\mathrm{P}<0.001)$ in Figure 4A; $7 \mathrm{nM}(\mathrm{P}<0.05)$ and $70 \mathrm{nM}(\mathrm{P}<0.01)$ in Figure 4B). When HGFs were stimulated with the unheated and heated HSC70 ATPase fragments, the levels of IL- 6 and IL- 8 were similar to those in unstimulated cells. These results suggest that HSC70 induces inflammatory cytokine production in HGFs.

\section{Inhibitory effect of anti-TLR antibodies on inflammatory cytokine production stimulated by $\mathrm{HSC70}$ in HGFs}

To examine whether inflammatory cytokine production stimulated by HSC70 was dependent on TLR2 or TLR4 in HGFs, we performed experiments using anti-TLR2 and anti-TLR4 antibodies. As shown in Figure 5A, levels of HSC70-stimulated IL-6 production in HGFs with anti-TLR4, anti-TLR2, and both antibodies significantly decreased $(\mathrm{P}<0.001)$. LPS-stimulated IL-6 production also significantly decreased in the presence of anti-TLR4 and both anti-TLR2 and anti-TLR4 antibodies $(\mathrm{P}<0.001)$. The patterns of HSC70- and LPS-stimulated IL-8 production in the presence of the antibodies were similar to those of IL-6 production under the same condition (Figure 5B). Next, we examined the effect of anti-CD14 antibody on HSC70- and LPS-stimulated inflammatory cytokine production in HGFs. HSC70-stimulated IL-6 and IL-8 production significantly decreased in the presence of this antibody $(\mathrm{P}<0.001)$ (Figures $5 \mathrm{C}$ and $5 \mathrm{D})$. The antibody also caused a decrease in cytokine production in LPSstimulated HGFs. The levels of IL- 6 and IL- 8 production under HSC70 stimulation were approximately1.6-fold higher than those by LPS stimulation. This behavior is similar to the previously reported findings for HSP70 stimulation of cytokine production through a CD14dependent pathway [37]. These results suggest that HSC70-stimulated inflammatory cytokine production in HGFs is dependent on TLR2, TLR4, and CD14.

\section{Inhibitory effect of histatin 3 on HSC70-stimulated inflammatory cytokine production in HGFs}

Histatin 3 was found to inhibit NF- $\mathrm{kB}$ activation through TLR2 and TLR4 (Figure 2). We then examined the effect of histatin 3 on HSC70-stimulated inflammatory cytokine production in HGFs. HSC70 and histatin 3 were added to HGFs, and the amounts of IL- 6 and IL- 8 released into the culture media were measured by ELISAs. As shown in Figures 6A and 6B, HSC70-stimulated cytokine production significantly decreased in the presence of histatin 3 , in a

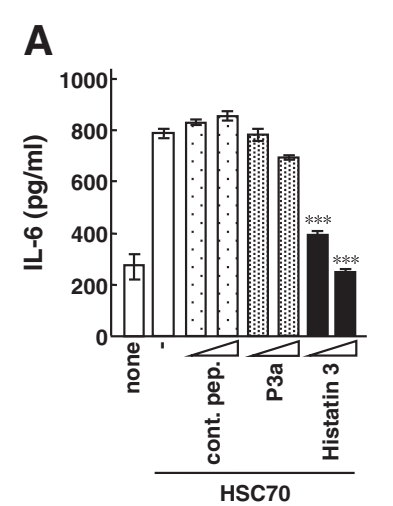

B
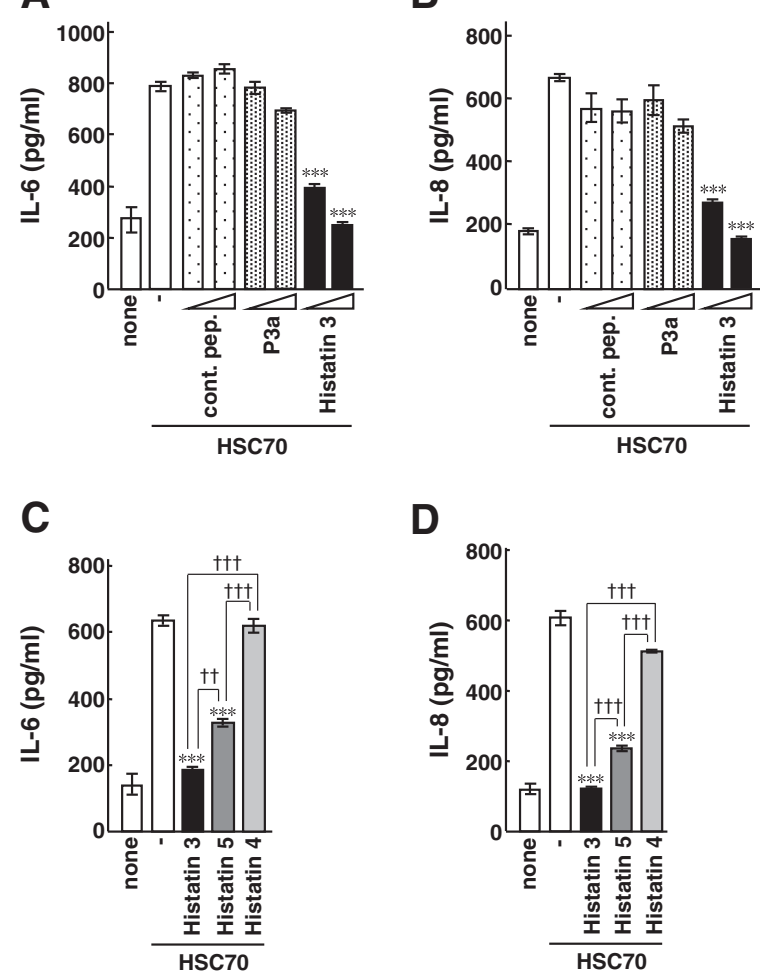

D

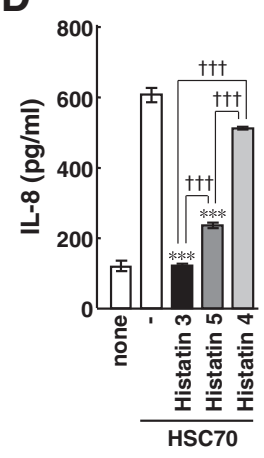

Figure 6 The effect of histatin 3 on HSC70-stimulated inflammatory cytokine production in HGFs. (A) HSC70-stimulated IL-6 and (B) IL-8 production in the presence of histatin 3 in HGFs. HGFs were stimulated with $\mathrm{HSC70}$ in the presence of control peptide (cont. pep.), P3a, or histatin 3 for $24 \mathrm{~h}$, and the amounts of IL-6 and IL-8 in the culture media were measured by ELISAs. Bars represent the means and range of duplicate samples. ${ }^{* *}, \mathrm{P}<0.001$ versus stimulation with HSC70 alone. (C) IL-6 and (D) IL-8 production in HGFs after stimulation with HSC70 in the presence of histatin family members. HGFs were stimulated with HSC70 in the presence of histatins 3, 4, or 5 for $24 \mathrm{~h}$, and the amounts of IL-6 and IL-8 in the culture media were measured by ELISAs. Bars represent the means and range of duplicate samples. ${ }^{* *}, \mathrm{P}<0.001$ versus stimulation with HSC70 alone. + , $\mathrm{P}<0.01$; + + , $\mathrm{P}<0.001$.

dose-dependent manner (histatin 3, $0.15 \mu \mathrm{M}(\mathrm{P}<0.001)$ and $1.5 \mu \mathrm{M}(\mathrm{P}<0.001))$. The control peptide and P3a did not appreciably affect the cytokine production. We then investigated whether other members of the histatin family were capable of inhibiting HSC70-stimulated cytokine production in HGFs. Histatins 3, 4, and 5 were mixed with HSC70 and used to stimulate HGFs, and the amounts of IL-6 and IL- 8 in the culture media were measured. As shown in Figures $6 \mathrm{C}$ and $6 \mathrm{D}$, the inhibitory effect of histatin 3 on the cytokine production was significantly higher than that of histatin 5 (IL-6, $\mathrm{P}<0.01$; IL- 8 , $\mathrm{P}<0.001)$. These results suggest that histatin 3 is an inhibitory factor of HSC70-stimulated inflammatory cytokine production in HGFs. 
Effects of histatin 3 on HSC70-stimulated MAPK phosphorylation and IKB-a degradation in HGFs

We next examined whether HSC70 stimulated MAPKs (extracellular signal-regulated kinases (ERK (p42/44)), JNK, and p38) phosphorylation and IкB- $\alpha$ degradation in HGFs. HGFs were cultured with HSC70 for 10, 30, and $60 \mathrm{~min}$, and extracted proteins were analyzed by Western blotting with anti-MAPK and anti-IкB- $\alpha$ antibodies. As shown in Figures 7A and 7B, enhanced phosphorylation of $\mathrm{p} 42 / 44$, JNK, p38, and IkB- $\alpha$ and stimulated significant degradation of IkB- $\alpha$ by HSC70 were observed. LPSs also stimulated significantly both the phosphorylation of MAPKs and IкB- $\alpha$ and the degradation of $\mathrm{I} \kappa \mathrm{B}-\alpha$.
To examine whether HSC70-induced ERK phosphorylation and $\mathrm{I}_{\kappa} \mathrm{B}-\alpha$ degradation were inhibited by histatin 3 , HGFs were stimulated with HSC70 in the presence of histatin 3, and Western blotting was performed. As shown in Figures 7C and 7D, p42/44 phosphorylation induced by HSC70 in the presence of histatin 3 was lower than that in the absence of histatin 3 or in the presence of the control peptide. Stimulation of either the control peptide or histatin 3 alone decreased levels of p42/44 phosphorylation. NF- $\mathrm{kB}$ activation by stimulation with the control peptide or histatin 3 alone was also diminished in 293-TLR4/MD2-CD14 and 293-TLR2/CD14 cells (Figures 2A and 2B). HSC70 stimulated $\mathrm{I} \kappa \mathrm{B}-\alpha$ degradation in the presence of the control peptide, but not

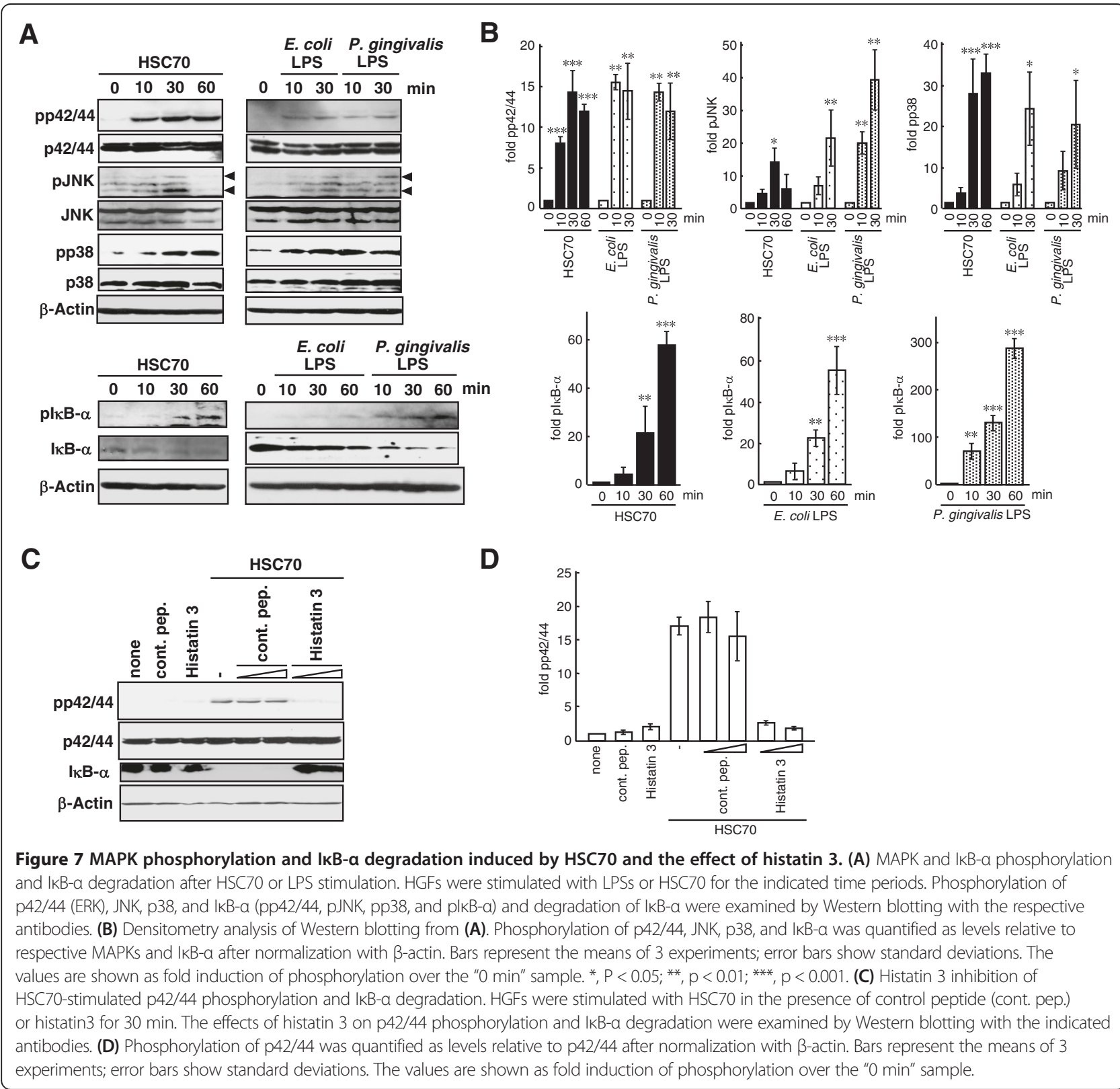


in the presence of histatin 3 . These results suggest that histatin 3 inhibits HSC70-mediated MAPK phosphorylation and IkB- $\alpha$ degradation in HGFs.

\section{Histatin 3 binding-induced protease-resistant conformation of $\mathrm{HSC70}$}

Histatin 3 prevented HSC70-stimulated NF-kB activation through TLR2 and TLR4 (Figure 2) and inflammatory cytokine production in HGFs (Figure 6). Therefore, we assumed that histatin 3 binding to HSC70 had some effect on the conformation of HSC70. To examine this assumption, HSC70 was mixed with histatin 3 , and the mixture was analyzed by limited V8 protease proteolysis. As shown in Figure 8, HSC70 with histatin 3 was relatively more resistant to digestion by $\mathrm{V} 8$ protease with HSC70 with the control peptide or P3a. Histatin 3 did not inhibit the activity of $\mathrm{V} 8$ protease (data not shown). These results suggest that histatin 3 may affect the conformation of $\mathrm{HSC70}$ upon binding.

\section{Discussion}

It has been reported that extracellular HSP70 induces inflammatory cytokine production through TLR2 and TLR4 pathway in human monocytes [25]. However, it is not known whether HSC70 activates TLR2 and TLR4 signaling in oral cells, and if so, whether intravital (bioactive) factors that inhibit HSC70 function exist in saliva. In this study, we found that HSC70, along with MD2/CD14, stimulated TLR4 and that HSC70, along with CD14, stimulated TLR2, resulting in the induction of NF- $\mathrm{kB}$-dependent activation. HSC70 also induced inflammatory cytokine production, MAPK phosphorylation, and IкB- $\alpha$ degradation in HGFs. Histatin 3

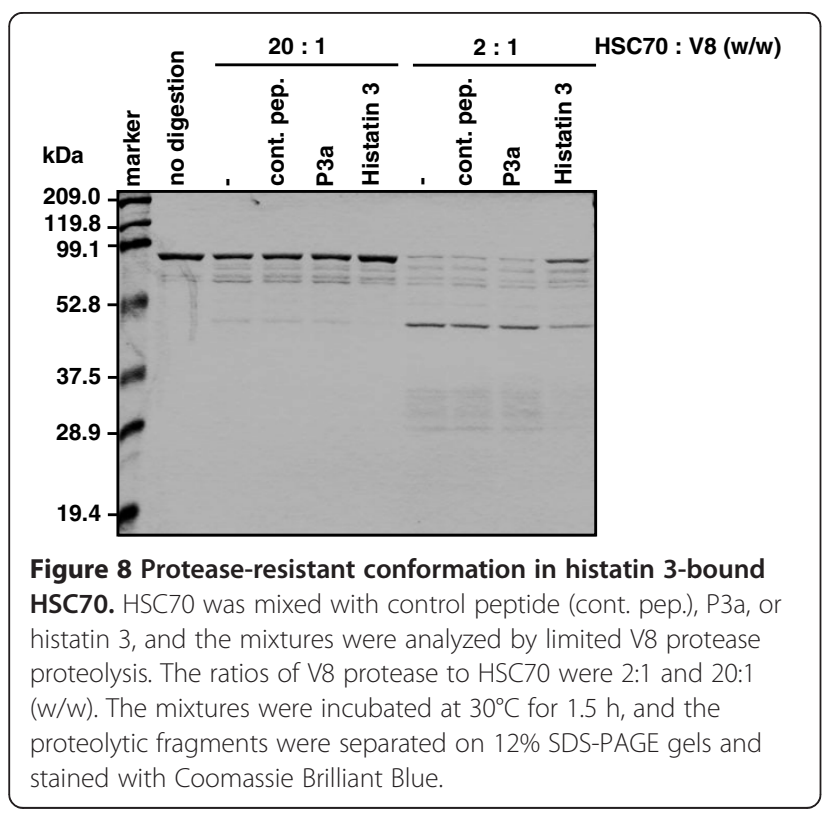

inhibited those effects of HSC70. Moreover, we believe that histatin 3 may affect conformation of HSC70 upon binding, presumably inhibiting HSC70 function.

In experiments related to TLR stimulation, stimulating reagents might be contaminated with endotoxin. Our studies showed that boiling $\left(95^{\circ} \mathrm{C}, 20 \mathrm{~min}\right)$ abrogated the effects of HSC70 induction, but not of LPS induction (Figure 1A). Moreover, polymyxin B, an LPS antagonist, abrogated the effects of LPS induction, but not of HSC70 induction (data not shown). In addition, endotoxin activity in the HSC70 reagents was analyzed by the limulus amebocyte lysate (LAL) assay and was found to be low. A recent study has revealed that TLR4 activation is induced by the HSP70 reagents which may include a small amount of endotoxin. The results of the study suggest that the stimulatory effect depends on HSP70, even in the presence of a small amount of endotoxin, and the structural integrity of HSP70 is essential [42]. Our results showed that histatin 3 significantly inhibits HSC70stimulated NF- $\mathrm{KB}$ activation and inflammatory cytokine production, despite a slight contamination of HSC70 reagents with endotoxins (Figures $2 \mathrm{~A}$ and 6). Consequently, we can conclude that $\mathrm{HSC} 70$ provably affects NF- $\mathrm{kB}$ activation and inflammatory cytokine production and histatin 3 may inhibit those effects upon its binding to HSC70. It is also possible that reagents used in stimulating experiments were contaminated with lipoproteins. We observed a decrease in the levels of NF- $\kappa B$ activation after stimulation with heated HSC70 (Figure 1C). Furthermore, the levels of inflammatory cytokine production after treatment with heated HSC70 were very low (Figure 4). In addition, histatin 3 significantly inhibited NF- $\mathrm{kB}$ activation and inflammatory cytokine production caused by HSC70 stimulation (Figures 2B and 6), although HSPs possess an affinity for lipids [43,44]. It is also difficult to precisely quantify the small amount of HSC70 associated with lipids in the HSC70 reagents. Consequently, if the HSC70 reagents contain HSC70 associated with lipids (even to a very small extent), our results might reflect the function of HSC70 in various physiological forms (for example, HSC70 that exists under the various physiological conditions of the oral cavity), because HSC70 derived from the cells might form lipoproteins $[42,43]$. We can conclude that histatin 3 binding to HSC70 may inhibit HSC70 activity.

A previous study has reported that HSC70 is released from injured cells [45]. The release of HSC70 from glial and $\mathrm{K} 562$ erythroleukemic cells has been also observed $[46,47]$. Our findings show that extracellular HSC70 stimulates TLR2 and TLR4 and increases the production of inflammatory cytokines in HGFs (Figure 4). Therefore, we suggest that HSC70 as well as other HSPs (e.g., HSP70 and HSP60) may function as a DAMP for TLRs and elicit inflammatory responses. The release of HSC70 
has also been observed in the heart, contributing to the postischemic myocardial inflammatory response and to cardiac dysfunction [48]. Inflammatory response in the oral cavity is also observed in oral diseases and injuries. It is tempting to speculate that HSC70 released from the damaged cells may stimulate oral cells such as HGFs. Our present findings suggest that inflammatory cytokine production stimulated by the released HSC70 might be inhibited by histatin 3 in saliva in HGFs, histatin 3 may be involved in inflammatory processes in the oral cavity.

Our previous study demonstrated the HSC70-binding ability of histatins [7]. The study showed that histatin 3 bound to the substrate-binding domain of HSC70 more strongly than histatin 5 and that histatin 4 did not bind to HSC70. Our present findings indicate that the inhibitory effects of histatin 5 on HSC70-stimulated NF-kB-dependent activation and inflammatory cytokine production significantly reduced compared with those of histatin 3 (Figures 2C, 2D, 6C, and 6D). Consequently, the strength of the association between various histatins and HSC70 may be related to the function of the complex.

In addition, it seems very likely that the primary structure of HSC70 is necessary for the function of HSC70 in TLR-mediated processes. Our findings showed that fulllength HSC70 and not the HSC70 ATPase fragment, can stimulate TLRs (Figures 1 and 4). In fact, a previous study reported that the substrate-binding domain of HSC70 is required to induce the myocardial inflammatory response [48]. In addition, conformation of HSC70 is also important for its correct functioning. Our findings show that a relatively protease-resistant conformation is formed upon histatin 3 binding to HSC70, but not in the presence of the control peptide, P3a (Figure 8), or DSG (data not shown). These results imply the possibility that there are some effects on conformation of HSC70. In fact, previous studies have reported that the peptide-binding domain of HSC70, as well as the ATPase domain of DnaK (the E. coli homo$\log$ of HSC70) is capable of undergoing conformational changes [49-51]. Thus, both the primary structure and other conformations of HSC70 may contribute to the activation of TLR signaling.

The innate host defense system recognizes foreign substances and tries to decrease their effects. One of the various host defense factors, pulmonary surfactant protein A downregulates the activation of TLR2 signaling by PGN [52]. An inhibitory peptide of TLR signaling, P13, inhibits both in vitro and in vivo LPS-induced inflammatory responses [53]. However, the precise mechanisms of this action have not been clarified. Histatin 3 is a peptide that binds directly to HSC70 and inhibits HSC70-induced TLR2 and TLR4 cell signaling (Figures 2, 6, and 7). Therefore, the results presented here provided the first evidence that histatin 3 is a salivary bioactive molecule. This molecule may prevent early-stage TLR signaling activation by interacting with TLR stimulators (ligands), such as HSC70, a putative ligand found in the oral cells.

\section{Conclusion}

In this study, we demonstrated the production of inflammatory cytokines in oral cells constitutively expressing HSP and the inhibition of this production by a salivary protein. Thus, this salivary protein has anti-inflammatory activity as well as already reported antimicrobial activity. It is possible that this salivary protein may resolve the HSPmediated inflammatory response in the oral cavity. The present findings further our understanding of the functions and mechanisms of actions of salivary proteins.

\section{Abbreviations}

DMEM: Dulbecco's modified Eagle medium; DSG: 15-deoxyspergualin; ELISA: Enzyme-linked immunosorbent assay; ERK: Extracellular signal-regulated kinases; EU: Endotoxin units; FBS: Fetal bovine serum; HGFs: Human gingival fibroblasts; HSC70: Heat shock cognate protein 70; HSP: Heat shock protein; IL: Interleukin; JNK: JUN-N-terminal protein kinase; LAL: Limulus amebocyte lysate; LPS: Lipopolysaccharide; MAPK: Mitogen-activated protein kinase; NF-kB: Nuclear factor-kB; PGN: Peptidoglycan; TLR: Toll-like receptor.

\section{Competing interests}

The authors declare that they have no competing interests.

\section{Authors' contributions}

Yl designed, conducted, analyzed and interpreted the data, and prepared the figures and manuscript. PLW designed and interpreted data, and helped prepare the manuscript. Both authors read and approved the final manuscript.

\section{Acknowledgements}

This work was supported by a Grant-in-Aid for Scientific Research (C) from the Ministry of Education, Culture, Sports, Science and Technology.

\section{Author details}

'Department of Pharmacology, Matsumoto Dental University, Shiojiri, Nagano, Japan. ${ }^{2}$ Department of Dental Education Innovation, Osaka Dental University, Hirakata, Osaka, Japan.

Received: 1 December 2012 Accepted: 30 January 2014

Published: 4 February 2014

\section{References}

1. Tenovuo J: Antimicrobial function of human saliva - how important is it for oral health? Acta Odontol Scand 1998, 56:250-256.

2. Troxler RF, Offner GD, Xu T, Vanderspek JC, Oppenheim FG: Structural relationship between human salivary histatins. J Dent Res 1990, 69:2-6.

3. Lal K, Pollock JJ, Santarpia RP 3rd, Heller HM, Kaufman HW, Fuhrer J, Steigbigel RT: Pilot study comparing the salivary cationic protein concentrations in healthy adults and AIDS patients: correlation with antifungal activity. J Acquir Immune Defic Syndr 1992, 5:904-914.

4. Gusman H, Leone C, Helmerhorst EJ, Nunn M, Flora B, Troxler RF, Oppenheim FG: Human salivary gland-specific daily variations in histatin concentrations determined by a novel quantitation technique. Archs Oral Biol 2004, 49:11-22.

5. Perinpanayagam HER, VanWuyckhuyse BC, Ji ZS, Tabak LA: Characterization of low-molecular-weight peptides in human parotid saliva. J Dent Res 1995, 74:345-350.

6. Li XS, Reddy MS, Baev D, Edgerton M: Candida albicans Ssa1/2P is the cell envelope binding protein for human salivary histatin 5. J Biol Chem 2003, 278:28553-28561.

7. Imamura Y, Fujigaki Y, Oomori Y, Usui S, Wang P-L: Cooperation of salivary protein histatin 3 with heat shock cognate protein 70 relative to the $\mathrm{G}_{1} / \mathrm{S}$ transition in human gingival fibroblasts. J Bio/ Chem 2009, 284:14316-14325.

8. Xu T, Levitz SM, Diamond RD, Oppenheim FG: Anticandidal activity of major human salivary histatins. Infect Immun 1991, 59:2549-2554. 
9. Oppenheim FG, Xu T, McMillian FM, Levitz SM, Diamond RD, Offner GD, Troxler RF: Histatins, a novel family of histidine-rich proteins in human parotid secretion. Isolation, characterization, primary structure, and fungistatic effects on Candida albicans. J Biol Chem 1988, 263:7472-7477.

10. Colon JO, Xu T, Oppenheim FG: Bactericidal effect of salivary histatin-5 on Porphyromonas gingivalis [abstract No. 1751]. J Dent Res 1993, 72:322.

11. Murakami Y, Nagata H, Shizukuishi S, Nakashima K, Okawa T, Takigawa M, Tsunemitsu A: Histatin as a synergistic stimulator with epidermal growth factor of rabbit chondrocyte proliferation. Biochem Biophys Res Commun 1994, 198:274-280

12. Lindquist S, Craig EA: The heat-shock proteins. Annu Rev Genet 1988, 22:631-677

13. Ellis RJ, van der Vies SM: Molecular chaperones. Annu Rev Biochem 1991, 60:321-347

14. McKay DB: Stracture and mechanism of 70-kDa heat shoch-related proteins. Adv Prot Chem 1993, 44:67-97.

15. Bukau B, Horwich AL: The Hsp70 and Hsp60 chaperone machines. Cell 1998, 92:351-366.

16. O'Malley K, Mauron A, Barchas JD, Kedes L: Constitutively expressed rat mRNA encoding a 70-kilodalton heat-shock-like protein. Mol Cell Biol 1985, 5:3476-3483.

17. Tsukahara F, Maru Y: Identification of novel nuclear export and nuclea localization-related signals in human heat shock cognate protein 70 . J Biol Chem 2004, 279:8867-8872.

18. Flaherty KM, DeLuca-Flaherty C, McKay DB: Three-dimensional structure of the ATPase fragment of a $70 \mathrm{~K}$ heat-shock cognate protein. Nature 1990, 346:623-628.

19. Kabsch W, Mannherz HG, Suck D, Pai EF, Holmes KC: Atomic structure of the actin:DNase I complex. Nature 1990, 347:37-44.

20. Medzhitov R, Preston-Hurlburt P, Janeway CA Jr: A human homologue of the Drosophila Toll protein signals activation of adaptive immunity Nature 1997, 388:394-397.

21. Rock FL, Hardiman G, Timans JC, Kastelein RA, Bazan JF: A family of human receptors structurally related to Drosophila Toll. Proc Natl Acad Sci USA 1998, 95:588-593.

22. Bianchi ME: DAMPs, PAMPs and alarmins: all we need to know about danger. J Leukoc Biol 2007, 81:1-5.

23. Takeuchi O, Hoshino K, Kawai T, Sanjo H, Takada H, Ogawa T, Takeda K, Akira S: Differential roles of TLR2 and TLR4 in recognition of gramnegative and gram-positive bacterial cell wall components. Immunity 1999, 11:443-451.

24. Hirschfeld M, Weis JJ, Toshchakov V, Salkowski CA, Cody MJ, Ward DC, Qureshi N, Michalek SM, Vogel SN: Signaling by toll-like receptor 2 and 4 agonists results in differential gene expression in murine macrophages. Infect Immun 2001, 69:1477-1482

25. Asea A, Rehli M, Kabingu E, Boch JA, Bare O, Auron PE, Stevenson MA, Calderwood SK: Novel signal transduction pathway utilized by extracellular HSP70: role of toll-like receptor (TLR) 2 and TLR4. J Biol Chem 2002, 277:15028-15034.

26. Poltorak A, He X, Smirnova I, Liu MY, Van Huffel C, Du X, Birdwell D, Alejos E, Silva M, Galanos C, Freudenberg M, Ricciardi-Castagnoli P, Layton B, Beutler B: Defective LPS signaling in $\mathrm{C} 3 \mathrm{H} / \mathrm{HeJ}$ and $\mathrm{C} 57 \mathrm{BL} / 10 \mathrm{ScCr}$ mice: mutations in Tlr4 gene. Science 1998, 282:2085-2088.

27. Ohashi K, Burkart V, Flohé S, Kolb H: Heat shock protein 60 is a putative endogenous ligand of the toll-like receptor-4 complex. J Immunol 2000 164:558-561.

28. Vabulas RM, Braedel S, Hilf N, Singh-Jasuja H, Herter S, Ahmad-Nejad P, Kirschning CJ, Da Costa C, Rammensee HG, Wagner H, Schild H: The endoplasmic reticulum-resident heat shock protein $\mathrm{Gp} 96$ activates dendritic cells via the Toll-like receptor 2/4 pathway. J Biol Chem 2002, 277:20847-20853.

29. Nagai $Y$, Akashi S, Nagafuku M, Ogata M, Iwakura Y, Akira S, Kitamura T, Kosugi A, Kimoto M, Miyake K: Essential role of MD-2 in LPS responsiveness and TLR4 distribution. Nat Immunol 2002, 3:667-672.

30. Means TK, Lien E, Yoshimura A, Wang S, Golenbock DT, Fenton MJ: The CD14 ligands lipoarabinomannan and lipopolysaccharide differ in their requirement for Toll-Like receptors. J Immunol 1999, 163:6748-6755.

31. Kawai T, Akira S: Toll-like receptors and their crosstalk with other innate receptors in infection and immunity. Immunity 2011, 34:637-650.

32. Lindhe J, Karring T, Lang PN: Clinical periodontology and implant dentistry. 4th edition. Copenhagen: Blackwell Munksgaard; 2003:19.
33. Uehara A, Takada H: Functional TLRs and NODs in human gingival fibroblasts. J Dent Res 2007, 86:249-254.

34. Watanabe A, Takeshita A, Kitano S, Hanazawa S: CD14-mediated signal pathway of Porphyromonas gingivalis lipopolysaccharide in human gingival fibroblasts. Infect Immun 1996, 64:4488-4494.

35. Imamura $Y$, Katahira T, Kitamura D: Identification and characterization of a novel BASH N terminus-associated protein, BNAS2. J Biol Chem 2004, 279:26425-26432.

36. Tsuji S, Okamoto M, Yamada K, Okamoto N, Goitsuka R, Alnold R, Kiefer F, Kitamura D: B cell adaptor containing src homology 2 domain (BASH) links $B$ cell receptor signaling to the activation of hematopoietic progenitor kinase 1. J Exp Med 2001, 194:529-539.

37. Asea A, Kraeft SK, Kurt-Jones EA, Stevenson MA, Chen LB, Finberg RW, Koo GC, Calderwood SK: HSP70 stimulates cytokine production through a CD14-dependant pathway, demonstrating its dual role as a chaperone and cytokine. Nat Med 2000, 6:435-442

38. Vabulas RM, Ahmad-Nejad P, Ghose S, Kirschning CJ, Issels RD, Wagner H: HSP70 as endogenous stimulus of the Toll/interleukin-1 receptor signal pathway. J Biol Chem 2002, 277:15107-15112.

39. DeLuca-Flaherty C, McKay DB, Parham P, Hill BL: Uncoating protein (hsc70) binds a conformationally labile domain of clathrin light chain LCa to stimulate ATP hydrolysis. Cell 1990, 62:875-887.

40. Nadler S, Tepper MA, Schacter B, Mazzucco CE: Interaction of the immunosuppressant deoxyspergualin with a member of the Hsp70 family of heat shock proteins. Science 1992, 258:484-486.

41. Nadeau K, Nadler SG, Saulnier M, Tepper MA, Walsh CT: Quantitation of the interaction of the immunosuppressant deoxyspergualin and analogs with Hsc70 and Hsp90. Biochemistry 1994, 33:2561-2567.

42. Luong M, Zhang Y, Chamberlain T, Zhou T, Wright J, Dower K, Hall JP: Stimulation of TLR4 by recombinant HSP70 requires structural integrity of the HSP70 protein itself. J Inflamm 2012, 9:11.

43. Guidon PT Jr, Hightower LE: Purification and initial characterization of the 71-kilodalton rat heat-shock protein and its cognate as fatty acid binding proteins. Biochemistry 1986, 25:3231-3239.

44. Guidon PT Jr, Hightower LE: The 73 kilodalton heat shock cognate protein purified from rat brain contains nonesterified palmitic and stearic acids. J Cell Physiol 1986, 128:239-245.

45. Saito K, Dai Y, Ohtsuka K: Enhanced expression of heat shock proteins in gradually dying cells and their release from necrotically dead cells. Exp Cell Res 2005, 310:229-236.

46. Tytell M: Release of heat shock proteins (Hsps) and the effects of extracellular Hsps on neural cells and tissues. Int J Hyperthermia 2005, 21:445-455.

47. Barreto A, Gonzalez JM, Kabingu E, Asea A, Fiorentino S: Stress-induced release of HSC70 from human tumors. Cell Immunol 2003, 222:97-104.

48. Zou N, Ao L, Cleveland JC Jr, Yang X, Su X, Cai GY, Banerjee A, Fullerton DA, Meng $X$ : Critical role of extracellular heat shock cognate protein 70 in the myocardial inflammatory response and cardiac dysfunction after global ischemia-reperfusion. Am J Physiol Heart Circ Physiol 2008, 294:H2805-H2813.

49. Schmid D, Baici A, Gehring H, Christen P: Kinetics of molecular chaperone action. Science 1994, 263:971-973.

50. McCarty JS, Buchberger A, Reinstein J, Bukau B: The role of ATP in the functional cycle of the DnaK chaperone system. J Mol Biol 1995, 249:126-137.

51. Buchberger A, Theyssen H, Schröder H, McCarty JS, Virgallita G, Milkereit P, Reinstein J, Bukau B: Nucleotide-induced conformational changes in the ATPase and substrate binding domains of the DnaK chaperone provide evidence for interdomain communication. J Bio/ Chem 1995, 270:16903-16910.

52. Murakami S, Iwaki D, Mitsuzawa H, Sano H, Takahashi H, Voelker DR, Akino T, Kuroki Y: Surfactant protein A inhibits peptidoglycan-induced tumor necrosis factor-alpha secretion in U937 cells and alveolar macrophages by direct interaction with toll-like receptor 2. J Biol Chem 2002, 277:6830-6837.

53. Tsung A, McCoy SL, Klune JR, Geller DA, Billiar TR, Hefeneider SH: A novel inhibitory peptide of Toll-like receptor signaling limits lipopolysaccharide-induced production of inflammatory mediators and enhances survival in mice. Shock 2007, 27:364-369.

doi:10.1186/1476-9255-11-4

Cite this article as: Imamura and Wang: Salivary histatin 3 inhibits heat shock cognate protein 70-mediated inflammatory cytokine production through toll-like receptors in human gingival fibroblasts. Journal of Inflammation 2014 11:4 